\title{
DISCLAIMER
}

This report was prepared as an account of work sponsored by an agency of the United States Government. Neither the United States Government nor any agency thereof, nor any of their employees, makes any warranty, express or implied, or assumes any legal liability or responsibility for the accuracy, completeness, or usefulness of any information, apparatus, product, or process disclosed, or represents that its use would not infringe privately owned rights. Reference herein to any specific commercial product, process, or service by trade name, trademark, manufacturer, or otherwise does not necessarily constitute or imply its endorsement, recommendation, or favoring by the United States Government or any agency thereof. The views and opinions of authors expressed herein do not necessarily state or reflect those of the United States Government or any agency thereof.

\section{National High-Level Waste Systems Analysis Report}

\author{
K. Kristofferson \\ T. P. Oholleran \\ R. H. Powell
}

Published September 1995

\section{Idaho National Engineering Laboratory Lockheed Idaho Technologies Company Idaho Falls, Idaho 83415}

\author{
Prepared for the \\ U.S. Department of Energy \\ Assistant Secretary for Environmental Management \\ Under DOE Idaho Operations Office \\ Contract DE-AC07-94ID13223
}




\section{DISCLAIMER}

Portions of this document may be illegible in electronic image products. Images are produced from the best available original document. 


\begin{abstract}
This report documents the assessment of budgetary impacts, constraints, and repository availability on the storage and treatment of high-level waste and on both existing and pending negotiated milestones. The impacts of the availabilities of various treatment systems on schedule and throughput at four Department of Energy sites are compared to repository readiness in order to determine the prudent application of resources. The information modeled for each of these sites is integrated with a single national model. The report suggests a high-level-waste model that offers a national perspective on all high-level waste treatment and storage systems managed by the Department of Energy.
\end{abstract}




\section{EXECUTIVE SUMMARY}

The Department of Energy currently has no mechanism with which to gain a systematized, interrelated national perspective on all the high-level waste treatment and storage systems that the Department manages.

This report documents the development of a model to assess, on a national basis, the impacts budgetary constraints, technology development and the availability of repositories could have on storage and treatment for high-level waste at four Department of Energy sites. The information acquired by modeling each of these sites is then integrated into one model, resulting in the national model.

The model, was developed using a given set of assumptions, and available hard data pertaining to schedules, processing options, and throughput. Qualitative factors can be evaluated with the model by creating discrete sets of input variables (scenarios). Treatment processes are modeled in sufficient detail to allow calculation of low-level and certain hazardous waste streams generated as a result of high-level waste treatment.

Six scenarios were examined with the model, using a simulation environment called Vensim. These six are: Scenario 1, Base Case; Scenario 2, No Repository; Scenario 3, Reduced Throughput at Various Facilities; Scenario 4, Repository Delayed 30 Years; Scenario 5, Repository Delayed 30 Years, Milestones Renegotiated; Scenario 6, Delay Vitrification at the INEL to Optimize Hanford Funding.

The model uses four types of variables to track systems performance: start dates, end dates, throughputs, and capacities. Waste treatment at each site is modeled by three functions: storage, treatment, and interim storage of high-level waste.

In the Base Case scenario, the repository begins accepting HLW on schedule in 2015. All waste glass is shipped from the West Valet Demonstration Project in the first year of repository operation to facilitate closure of the West Valley site. Results show that interim storage at Savannah River and the INEL can be minimized by shipping at the respective production rates with minimal impact on Hanford.

Scenario 2 assumes indefinite delay of HLW acceptance at a repository. Results from this simulation show maximum interim storage capacity needed at each site as a function of time.

For Scenario 3, production and shipping schedules for the low-level waste streams at West Valley and Savannah River are the same as in the base case scenario, Production rates at Hanford and the INEL are reduced by $30 \%$ to simulate downsized facilities. As a result of the reduced production rates, Hanford and the INEL minimize interim storage by shipping glass to the repository at their respective production rates. In addition, interim storage requirements at Savannah River are reduced and can be emptied sooner as a result of reduced demand for repository resources by Hanford and the INEL.

Scenario 4 illustrates the effect of a 3 year delay in the repository HLW acceptance. All sites must provide a maximum interim storage in this scenario, although storage at the INEL remains full for only one year.

For Scenario 5, the schedules at West Valley and Savannah River are the same as in the base case scenario, but production at Hanford and the INEL is delayed 30 years to coincide with the 30 year delay in the repository acceptance of $\mathrm{HLW}$. The production delay minimizes interim storage at Hanford and the INEL and assumes re-negotiation of milestones. 
For Scenario 6, the schedules at West Valley, Savannah River and Hanford are the same as the base case scenario, production at the INEL is delayed until production ends at Hanford. This scenario optimizes funding at Hanford but extends production at the-INEL

The most obvious strategy for minimizing facility cost is to minimize or eliminate the need for interim storage facilities. A technical and cost/benefit analysis should be performed to evaluate the possibility of using INEL's calcining technology on Hanford's high-level liquid waste to reduce the risk of interim storage, and allow vitrification to be delayed until a repository is ready. 


\section{CONTENTS}

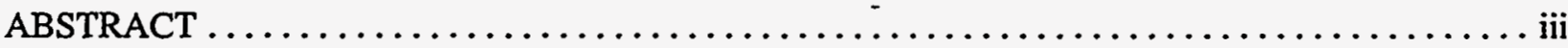

EXECUTIVE SUMMARY $\ldots \ldots \ldots \ldots \ldots \ldots \ldots \ldots \ldots \ldots \ldots \ldots \ldots \ldots \ldots \ldots \ldots \ldots$

ACRONYMS $\ldots \ldots \ldots \ldots \ldots \ldots \ldots \ldots \ldots \ldots \ldots \ldots \ldots \ldots \ldots \ldots \ldots \ldots \ldots \ldots \ldots \ldots \ldots \ldots \ldots$

1. INTRODUCTION $\ldots \ldots \ldots \ldots \ldots \ldots \ldots \ldots \ldots \ldots \ldots \ldots \ldots \ldots \ldots \ldots \ldots \ldots \ldots \ldots$

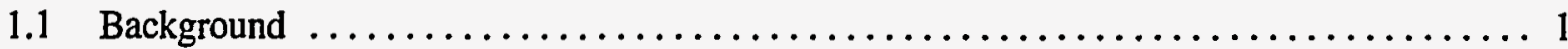

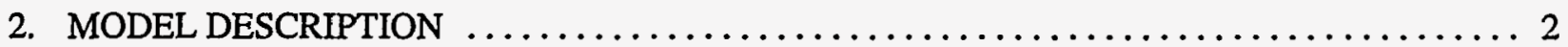

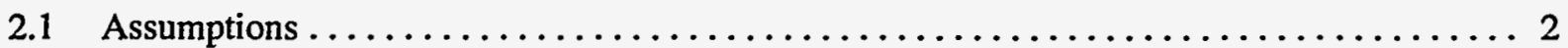

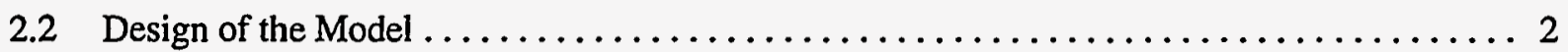

2.3 Operation of the Model $\ldots \ldots \ldots \ldots \ldots \ldots \ldots \ldots \ldots \ldots \ldots \ldots \ldots \ldots \ldots$

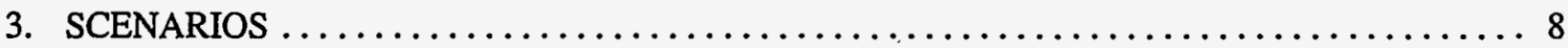

3.1 Scenario 1: Base Case $\ldots \ldots \ldots \ldots \ldots \ldots \ldots \ldots \ldots \ldots \ldots \ldots \ldots \ldots \ldots \ldots \ldots$

3.2 Scenario 2: No Repository $\ldots \ldots \ldots \ldots \ldots \ldots \ldots \ldots \ldots \ldots \ldots \ldots \ldots \ldots \ldots$

3.3 Scenario 3: Reduced Throughput at Various Facilities $\ldots \ldots \ldots \ldots \ldots \ldots \ldots \ldots \ldots$

3.4 Scenario 4: Repository Delayed 30 Years $\ldots \ldots \ldots \ldots \ldots \ldots \ldots \ldots \ldots \ldots$

3.5 Scenario 5: Repository Delayed 30 Years, Milestones Renegotiated . . . . . . . . . . 9

3.6 Scenario 6: Delay Vitrification at the INEL to Optimize Hanford Funding $\ldots \ldots \ldots \ldots 10$

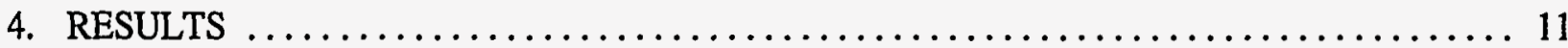

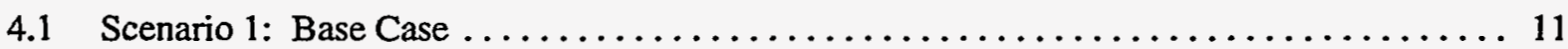

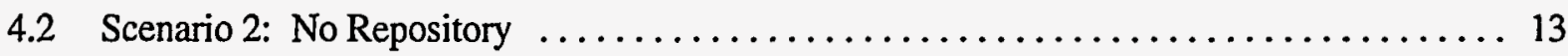

4.3 Scenario 3: Reduced Throughput $\ldots \ldots \ldots \ldots \ldots \ldots \ldots \ldots \ldots \ldots \ldots \ldots \ldots \ldots \ldots$

4.4 Scenario 4: Delay Repository Opening 30 Years $\ldots \ldots \ldots \ldots \ldots \ldots \ldots \ldots \ldots \ldots$

4.5 Scenario 5: Delay Repository Opening 30 Years and Renegotiate Milestones ........ 16

4.6 Scenario 6: Delay Vitrification at INEL to Optimize Hanford Funding $\ldots \ldots \ldots \ldots \ldots$

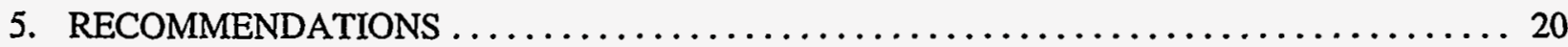

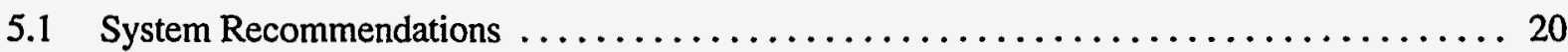




\section{FIGURES}

1. Schematic representation of the site-specific portion of the systems analysis model.

Variables are shown in parenthesis. The treatment function is a rollup of site-specific flow sheets (actual or proposed), and therefore can be used to account for secondary waste streams

2. Two variables (shown in parenthesis) were used to model the transportation and disposal parts of the HLW system. Waste treated at the individual sites flows through the transportation system at an integrated rate defined by the variable (throughput) and accumulates at the repository until the variable (capacity) is reached. The areas of responsibility of EM and RW are illustrated by the dashed boxes

3. System Interim Storage Requirements as a function of time (year). The initial slope is attributable to production at SRS, with a brief contribution from WVDP in 1997 and 1998. The steep increase in slope is a result of the start of production at Hanford in 2009. Shipments to the repository begin in 2014. Production at SRS is complete in 2020, and at Hanford in 2028. These events are all marked by decreases in slope $\ldots \ldots \ldots \ldots \ldots \ldots \ldots$

4. The amount of glass in interim storage at each site as a function of time. Shipments to the repository start in 2015. Interim storage at West Valley is emptied in the first year

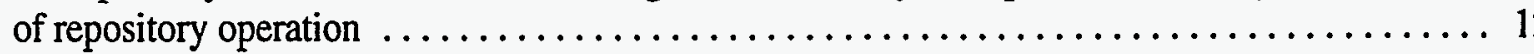

5. The volume of HLW glass in the repository as a function of time (year). The slope between 2039 and 2044 is slightly positive because the INEL is still shipping glass at the rate of $16 \mathrm{~m}^{3}$ per year

6. Waste glass emplaced in interim storage at each site as a function of time, assuming repository opening is delayed indefinitely. Interim storage construction schedules can be developed

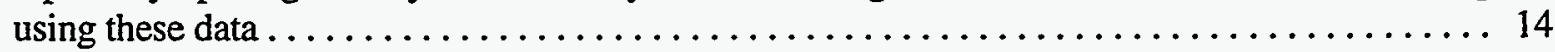

7. Glass in interim storage at each site as a function of time. The need for interim storage at Hanford and the INEL is essentially eliminated by delaying production at those sites until the repository opens

8. Waste glass inventory at each site as a function of time. In this scenario, each site must provide interim storage capacity for the total amount of waste glass produced. The end of production for a given site is indicated by the point where the interim storage vs. time curve changes from positive to zero 
9. Site interim storage inventories as a function of time. The ends of production for SRS and West Valley are indicated by the points where the interim storage vs. time curve changes from positive to zero. Interim storage must be provided for all waste glass produced at the SRS and West Valley, but concurrent production and shipping schedules minimize interim storage capacities at Hanford and the INEL $\ldots \ldots \ldots \ldots \ldots \ldots \ldots \ldots \ldots$

10. Glass in interim storage at each site as a function of time. System interim storage inventory goes to zero in 2037, but production at (and shipment from) the INEL extends to 2063

\section{TABLES}

1. Low-level waste streams generated by $\mathrm{HLW}$ processing at each site

2. Maximum interim storage capacity by site, assuming repository opening is delayed indefinitely

3. Top-level milestones from Hanford's Tri-Party Agreement that would be renegotiated under this scenario. Sub-tier milestones would also be renegotiated

4. Top-level milestones from the INEL's NON Consent Order that would be renegotiated under this scenario. Sub-tier milestones would also be renegotiated 


\section{ACRONYMS}

$\begin{array}{ll}\text { CFR } & \text { Code of Federal Regulations } \\ \text { DOE } & \text { Department of Energy } \\ \text { EIS } & \text { Environmental Impact Statement } \\ \text { EM } & \text { Environmental Management } \\ \text { ER\&WM } & \text { Environmental Restoration and Waste Management } \\ \text { HLLW } & \text { high-level liquid waste } \\ \text { HLW } & \text { high-level waste } \\ \text { INEL } & \text { Idaho National Engineering Laboratory } \\ \text { LLW } & \text { low-level waste } \\ \text { NON } & \text { notice of noncompliance } \\ \text { OCRWM } & \text { Office of Civilian Radioactive Waste Management (also RW) } \\ \text { ROD } & \text { Record of Decision } \\ \text { SNF } & \text { spent nuclear fuel } \\ \text { SRS } & \text { Savannah River Site } \\ \text { SSTs } & \text { single-shell tanks } \\ \text { WASRD } & \text { Waste Acceptance System Requirements Document } \\ \text { WVDP } & \text { West Valley Demonstration Project } \\ \end{array}$




\section{National High-Level Waste Systems Analysis Report 1. INTRODUCTION}

\subsection{Background}

At the present time, no mechanism exists that affords a systematic, interrelated view or national perspective of all high-level waste (HLW) treatment and storage systems that the U.S. Department of Energy (DOE) manages. The impacts of budgetary constraints and repository availability on storage and treatment must be assessed against existing and pending negotiated milestones for their impact on the overall HLW system. This assessment can give DOE a complex-wide view of the availability of waste treatment and help project the time required to prepare HLW for disposal.

The complex array of facilities, throughputs, schedules, and milestones has been modeled to ascertain the treatment and storage "systems" resource requirements at the Hanford site, Savannah River Site (SRS), Idaho National Engineering Laboratory (INEL), and West Valley Demonstration Project (WVDP). The impacts of various treatment system availabilities on schedule and throughput were compared to repository readiness to determine the prudent application of resources. This process is documented in this report. To assess the various impacts, the model has been exercised against a number of plausible scenarios as discussed in this report.

Some HLW models are in existence, or have been developed at the site level. This model used the efforts of others where possible and researched site data to complete the picture. The INEL will encourage other sites and focus areas to use this model since it offers a truly national perspective.

It should be noted that this report was intended to be a compilation of the analysis done on a group of scenarios. This report is designed to show the impacts the DOE HLW system might experience under certain scenarios and was not intended to be used as policy development guidance. In addition, the scenarios depicted in the report were tormulated to enable the reader to understand the analysis capabilities of the model and in no way represent DOE-HQ policy or guidance. 


\section{MODEL DESCRIPTION}

\subsection{Assumptions}

The repository will have the capacity to accept all immobilized HLW. However, in the model, this variable can be changed to serve as an independent.variable to study the effects of different repository sizes and/or multiple repositories.

- $\quad$ For the base case, the repository will begin accepting HLW in 2015.

- Other wastes to be sent to the repository (such as commercial spent fuel) will not affect the shipment and handling and the capacity to dispose of HLW.

- No additional HLW will be generated.

- $\quad$ All HLW will be treated at the site where it is presently stored.

- Treatment options will be modeled either as established processes where construction is now under way (SRS and West Valley), or using the latest information available on the currently preferred process option where treatment technology is still under development.

- Sufficient interim storage will be available in time to accommodate waste form fabrication rates and repository shipment schedules.

- Immobilịzed waste will be shipped at the rates specified in Table 3-2 of the Waste Acceptance System Requirements Document (WASRD). These rates are actually rates of receipt at the repository and therefore represent the sum of waste shipments from all sites (refer to Figure 2). The exact distribution of shipping capacity among the sites will be specified for each scenario. (This assumption can be changed to serve as an independent variable reflecting limitations in repository handling capabilities and/or limitations in the transportation system.)

- $\quad$ All HLW sent to a repository will be delisted, have a treatability variance approved, or be treated by a process determined to be equivalent technology pursuant to 40 CFR 268 .

\subsection{Design of the Model}

The system model was constructed using available hard data pertaining to schedules, processing options, and throughput. The influence of qualitative factors (soft variables) can be evaluated with the model by establishing discrete sets of input variables (called scenarios) that reflect the consequences of soft variables. For example, the effects of stakeholder involvement could be modeled by manually setting certain schedule dates that are used as input by the model, and letting the model calculate detailed schedule and throughput rates needed to meet the fixed schedule. The potential need for additional resources, such as increased tank capacity, would also be estimated. Alternatively, schedule can be fixed in order to study the effects of legally binding agreements on facility size (throughput). Conversely, throughput can be fixed to examine the influence of budget constraints on the need to renegotiate existing agreements. Detailed schedules were developed from higher-level milestones, such as deadlines in Federal Facility Tri-Party Agreements, consent orders and Federal Facility Compliance Act driven consent orders. 
HLW currently in storage was modeled as a "source," and the HLW repository was modeled as the "sink." Detailed flow sheets describing the wastes and treatment processes (existing or proposed) at each site managing HLW were used to model the preparation of HLW for shipment to the repository. The waste treatment and interim storage portions of the system come under the purview of Environmental Management (EM). The Office of Civilian Radioactive Waste Management (OCRWM or RW) is responsible for the transportation and disposal activities of the system.

The model uses four types of variables to track system performance: start dates, end dates, throughputs, and capacities. The user can fix various combinations of these variables as independent variables, and allow the model to calculate the remaining variables as dependent variables. The model performs calculations as an incremental function of time to correlate throughput and capacity with schedule variables.

Waste treatment at each site is modeled by three top-level functions: HLW storage, treatment, and interim storage. Transfers between the functions are characterized by throughput variables. HLW storage and interim storage are characterized by capacities. The treatment function is derived as a rollup of detailed flow sheets describing the entire treatment process (existing or proposed) at each site. As such, the treatment function is described entirely by inputs, outputs and schedule information. This feature allows the model to account for secondary waste streams (such as low-level waste), in addition to the primary HLW stream.

The waste treatment operations at each site couple to the repository through the transportation system. Since the total throughput of the transportation system is used to regulate the flow of waste into the repository, each site must be assigned its specific allotment of the total throughput of the transportation system. This feature allows the user to study trade-offs among treatment rates, interim storage, shipping rates, and schedule variables. Input variables can be programmed as either simple on/off functions, or have values which vary with time or some other dependency. The design of the site-specific portions of the model are illustrated schematically in Figure 1.

The transportation system and waste packaging operations at the repository were liut explicitly modeled, but their effects were simulated by the rate of shipment of HLW to the repository. The rate of HLW shipment (and receipt and processing at the repository) is equivalent to the throughput of the transportation system. The approach used to model the relationship between the treatment and storage facilities and the disposal facility is shown schematically in Figure 2.

In the scenarios used for initial model development, the repository was assigned sufficient capacity to accept all HLW. Repository capacity could be reduced to study the effects of limited HLW repository space in the first repository, and to schedule and size a second repository.

\subsection{Operation of the Model}

A given set of independent variables represents a "scenario." Once a scenario has been defined, dependent variables are calculated to provide the output. The output includes event flags to indicate if pre-selected conditions are not satisfied by the dependent variables when a scenario is run. 


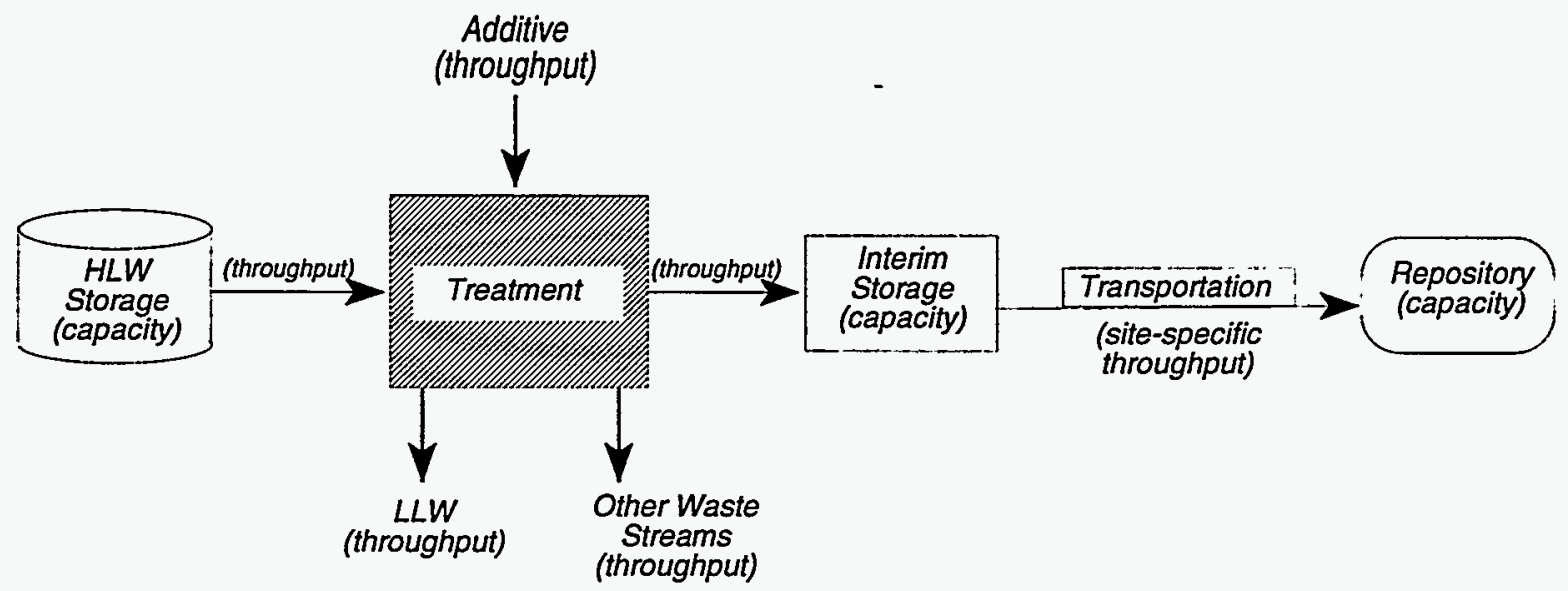

Figure 1. A generic schematic representation of the site-specific portion of the systems analysis model. Variables are shown in parenthesis. The treatment function is a rollup of site-specific flow sheets (actual or proposed), and therefore can be used to account for secondary waste streams.

Figure 2. Two variables (shown in parentheses) were used to model the transportation and disposal parts of the HLW system. Waste treated at the individual sites flows through the transportation system at an integrated rate defined by the variable (throughput) and accumulates at the repository until the variable (capacity) is reached. The areas of responsibility of EM and RW are illustrated by the dashed boxes. 
Six specific scenarios were examined with the model in order to efficiently develop the model and to demonstrate capabilities for further analysis.

The model is implemented using a simulation environment called Vensim, ${ }^{a}$ running under Microsoft Windows ${ }^{\circledR}$. Therefore, much of the operation of the model is based upon operation of the Vensim product.

Vensim allows the user to build continuous computer simulations (as opposed to discrete simulations). This means that the various treatment, storage, and disposal operations are represented in the computer as continuous flows of material. For the sake of consistency, units of cubic meters $\left(\mathrm{m}^{3}\right)$ are used for volumes, and cubic meters per year $\left(\mathrm{m}^{3} / \mathrm{yr}\right)$ are used for rates or flows.

The national model consists of five sub-models:

1. Hanford Nuclear Reservation

2. West Valley Demonstration Project

3. Savannah River Site

4. Idaho National Engineering Laboratory

5. The National Repository

Each of the sub-models corresponding to a national laboratory was developed individually, and then integrated to form the national model. At this time, the sub-model for the repository was added, and transportation connections were made between each of the four labs and the repository.

Each sub-model is contained within its own Vensim view, thereby improving the organization and usability of ihe model. The fifth view, entitled Repository, is the central view that connects the other four views. In addition, the Repository view contains global variables that are used throughout the entire model.

Once the integrated model became operational, we were able to use it for its intended purpose: analysis of the national system. This analysis is best accomplished by performing a series of "what-ifs" with the model, also known as scenario analysis. The development of a scenario analysis consists of the following steps:

1. Define the scenario: The scenario is first described loosely in English using the appropriate domain terminology. It is then refined and described in terms of the actual Vensim model, using actual Vensim variable names.

a. Vensim ${ }^{\circledast}$ is a product of:

Ventana ${ }^{\circledast}$ Systems, Inc.

149 Waverley Street

Belmont, Massachusetts 02178 USA

Phone: (617) 489-5249

Fax: (617) 489-5316 
2. Implement the scenario: The existing Vensim model equations are modified and new equations are created as necessary to support the implementation of the new scenario. The impact on the model depends on the scope of the changes dictated by the scenario.

3. Execute the scenario: The Vensim model is simulated over time using the equations that define the new scenario. The results are captured in a data file for use in step 4.

4. Analyze the scenario: The results from the run can be viewed as graphs and/or tables, and compared against the results from other scenarios. The person performing the analysis uses domain expertise to determine what impacts the scenario has on the system.

We will develop an example scenario using the above steps, in order to better illustrate the process. We will use the simple case of a delayed repository opening date:

1. Define the scenario: What happens if the federal repository does not open on the currently scheduled date? More specifically, what are the impacts on the national HLW system if the repository opening date is postponed a specified number of years? For the sake of consistency with scenarios that are used later in this report, we will choose a delay of 30 years. In the Vensim model, there is a variable in the Repository view called Repository $S D(S D=$ Start Date). This is the year in which the repository becomes available to receive HLW shipments. Usually the equation for this variable is simply a constant, the year 2015. For the purposes of this scenario we will change Repository SD to 2045.

2. Implement the scenario: In this case, implementing the scenario is trivial: In the Vensim Equation Editor the value for Repository SD is changed from 2015 to 2045.

Implementation of a scenarios can require substantial modification to the model. Modifications can be made for either one-time use or can be made more versatile, e.g., left on in the model permanently and activated when desired. This scenario was chosen as an example mainly because of its simplicity.

3. Execute the scenario: Once the scenario is implemented, execution is initiated by the user storing the results by selecting a unique name for each. This way the results from a particular scenario can be compared with others.

4: Analyze the scenario: When the scenario is executed, the results from the run are stored so that they can be viewed and analyzed in a variety of ways. The first step in analyzing the results is to choose the variable or variables that are impacted by the changes in the scenario. Since the repository opening date was delayed, we would like to see what impacts that change has on the rest of the HLW system. The areas most likely to be affected are the interim storage facilities at the four HLW sites. Therefore, the four variables we are interested in examining are: Hanford HLW IS (IS=Interim Storage), WV $H L W I S, S R S H L W I S, I N E L H L W I S$. The second step in analyzing the results is to produce a graph or table of the variables we are interested in. In Vensim, this is accomplished by selecting the variable, then clicking on the appropriate graph or table button. The graphs that Vensim produces are line graphs over time, and are useful for initial and comparative analysis. The tables show the actual numbers by time step, so that a more accurate and detailed analysis can be performed. 
The model was constructed with sufficient process detail that quantitative answers can be provided to specific technical questions. For example, if a scenario were constructed that required HLW treatment to shutdown prematurely because of insufficient repository,-interim storage volume or lack of resources, the model could be used to determine how much HLW remained in primary storage and in process-related temporary storage on site specific basis. This information could be used to evaluate standby status in the event of such a premature shutdown. 


\section{SCENARIOS}

\subsection{Scenario 1: Base Case}

The base case scenario uses a fixed schedule defined by existing court orders and agreements. Detailed waste treatment schedules were derived from current (3rd quarter of FY 1995) site-specific plans for waste immobilization (see references, section 6.0). Process throughputs were estimated from available flow sheet data, along with interim storage requirements. Process models and accompanying data for SRS and West Valley are considered complete and very accurate, because these sites are about to begin waste form production. The models and data for Hanford and the INEL are more preliminary in nature, reflecting the current state of development at those sites.

The transportation system and repository waste receipt operation are modeled as a throughput to repository storage having a maximum rate of $572 \mathrm{~m}^{3} / \mathrm{yr}$. Waste from West Valley is shipped at a rate that will allow interim storage to be emptied in one year. Waste from SRS is shipped at the production rate to avoid construction of new interim storage at that site after the repository begins accepting HLW. The remaining shipping capacity (throughput) is divided between Hanford and the INEL. The original plan was to assign shipping rates based on the ratio of the production rates at the two sites. For example, the shipping capacity assigned to Hanford $\left(\mathrm{S}_{\mathrm{H}}\right)$ is calculated as:

$$
S_{H} \frac{P_{H}}{P_{I}} S_{R} \quad S_{S} \quad S_{W}
$$

where

$$
\begin{aligned}
& \mathrm{P}_{\mathrm{H}}=\text { Hanford's production rate }\left(\mathrm{m}^{3} / \mathrm{yr}\right) \\
& \mathrm{P}_{\mathrm{I}} \quad=\quad \text { INEL's production rate }\left(\mathrm{m}^{3} / \mathrm{yr}\right) \\
& S_{R}=\text { total repository shipping (receipt) rate }=572 \mathrm{~m}^{3} / \mathrm{yr} \\
& \mathrm{S}_{\mathrm{S}}=\text { SRS's shipping rate }\left(\mathrm{m}^{3} / \mathrm{yr}\right) \\
& \mathrm{S}_{\mathrm{w}}=\text { WVDP's shipping rate }\left(\mathrm{m}^{3} / \mathrm{yr} \text { ) (goes to zero } \mathrm{m}^{3} / \mathrm{yr}\right. \text { after the first year of repository }
\end{aligned}
$$

\subsection{Scenario 2: No Repository}

This scenario uses the schedules and throughputs of the base case scenario, but storage capacity for all immobilized waste is provided by interim storage facilities. The maximum interim storage capacity that would be needed at each site was calculated, and throughput data that can be used to develop facility construction schedules were derived. Information from this scenario could also be used in cost studies to determine the optimum size of interim storage facilities. 


\subsection{Scenario 3: Reduced Throughput at Various Facilities}

This scenario perturbs the base case scenario by reducing throughputs between HLW storage and the treatment facility by $30 \%$ at sites where facilities neither exist presently nor are under construction (i.e., Hanford and the INEL). New schedules are calculated based on the reduced throughput. This scenario simulates a reduction in funding as a reduction in throughput to reflect downsized facilities. It is assumed that SRS and West Valley will operate as currently planned, because construction funds for those sites are already committed. This scenario illustrates how reduced funding could impact existing agreements and court orders.

Scenario 3 facilitates closure of the West Valley site, limits the need for interim storage capacity at SRS, and minimizes interim storage capacities at Hanford and the INEL. Interim storage capacities at Hanford and the INEL are minimized by delaying startup of HLW immobilization facilities until the repository is ready to receive waste shipments (2015). Startup dates for SRS and West Valley remain unchanged.

\subsection{Scenario 4: Repository Delayed 30 Years}

This scenario recomputed the base case (Scenario 1), with the repository opening being delayed 30 years (to 2045). This scenario illustrates the impact of a delay in repository operations on interim storage needs, and would require additional construction. This case assumed that all current agreements and court orders are or will be met, other than those requiring deep geologic disposal.

Minimization of interim storage can be accomplished by delaying startup of treatment at Hanford and the INEL until the repository opens. Production rates for both sites were the same as in the base case scenario. SRS and WVDP proceeded according to current schedules for waste immobilization. WVDP will ship waste at a rate sufficient to allow the site's interim storage to be emptied in one year. SRS will be assigned the remainder of the transportation throughput, until Hanford and the INEL come on line. At that time, SRS's share of the transportation throughput will be set equal to the production rate (throughput to interim storage), and the remainder of the transportation throughput will be divided between Hanford and the INEL. This scenario illustrates the latitude for adjustment in DOE's HLW treatment schedule, while minimizing interim storage costs and meeting all milestones in existing orders and agreements as discussed in Section 4.

\subsection{Scenario 5: Repository Delayed 30 Years, Milestones Renegotiated}

This scenario assumed a 30-year delay in repository operations, as in Scenario 4, and calculated new schedules for Hanford and the INEL to minimize interim storage at those sites. Minimization of interim storage was accomplished by delaying production until the repository began receiving waste.

The transportation throughput available to each site was determined from the total transportation throughput available to the two sites based on production rates at each site. Savannah River and West Valley proceeded according to current schedules for waste immobilization. West Valley shipped waste at a rate sufficient to allow the site's interim storage to be emptied in one year. Shipment schedules for SRS, Hanford, and the INEL were based on production rates at each site as described in Section 3.1. Savannah River's share of the transportation throughput was set equal to the production rate (throughput to interim storage) that was used while the site was producing waste forms. This scenario illustrates the latitude for adjustment in DOE's HLW treatment schedule while minimizing interim storage costs and helps define issues for renegotiating orders and agreements. 


\subsection{Scenario 6: Delay Vitrification at the INEL to Optimize Hanford Funding}

This scenario is similar to the base case (Scenario 1) except that the start of vitrification at the INEL is delayed until after vitrification is complete at Hanford in 2028. All High-Level Liquid Waste (HLLW) at the INEL would be calcined to provide safe interim storage until the vitrification plant becomes operational. While extending the time required to dispose of all $\mathrm{HLW}$, this scenario would reduce the maximum expenditures in the overall system funding curve, and allow DOE to optimize resource allocations for Hanford. In this scenario, vitrification of all HLW is complete in 2059, while in the base case, vitrification is complete in 2043. 


\section{RESULTS}

\subsection{Scenario 1: Base Case}

Total interim storage required by the system reaches a maximum of $5742 \mathrm{~m}^{3}$ in 2021 , and then decreases to zero by 2038. System interim storage requirements as a function of time are shown graphically in Figure 3.

While shipments to the repository are shown in this figure to begin in 2015 , system inventory continues to build until production ceases at SRS in 2020 because system production rate exceeds shipment/receipt rate during that time. When production ceases at Hanford, system inventory decreases until all interim storage is empty in 2038. However, shipments to the repository must continue until 2044, when production ceases at the last site (INEL). The amount of glass in interim storage at each site is shown as a function of time in Figure 4.

Based on the assumptions made in Scenario 1 (Base Case), the repository will accumulate HLW glass as shown in Figure 5. In order to fully use the repository receipt rate, shipment rates were calculated for each site, which divided up the maximum repository receipt rate among the four sites. This results in the constant slope from 2015 to 2039 . From 2039 to 2044 the slope is slightly positive because INEL is still shipping glass. For this initial model, no limits were placed on HLW capacity. However, scenarios, which place limits on HLW capacity, could be run in order to determine the impacts on the HLW system. Enforcement of such limits could correspond to physical capacity limitations as a result of the storage of other waste types in the repository, such as spent nuclear fuel.

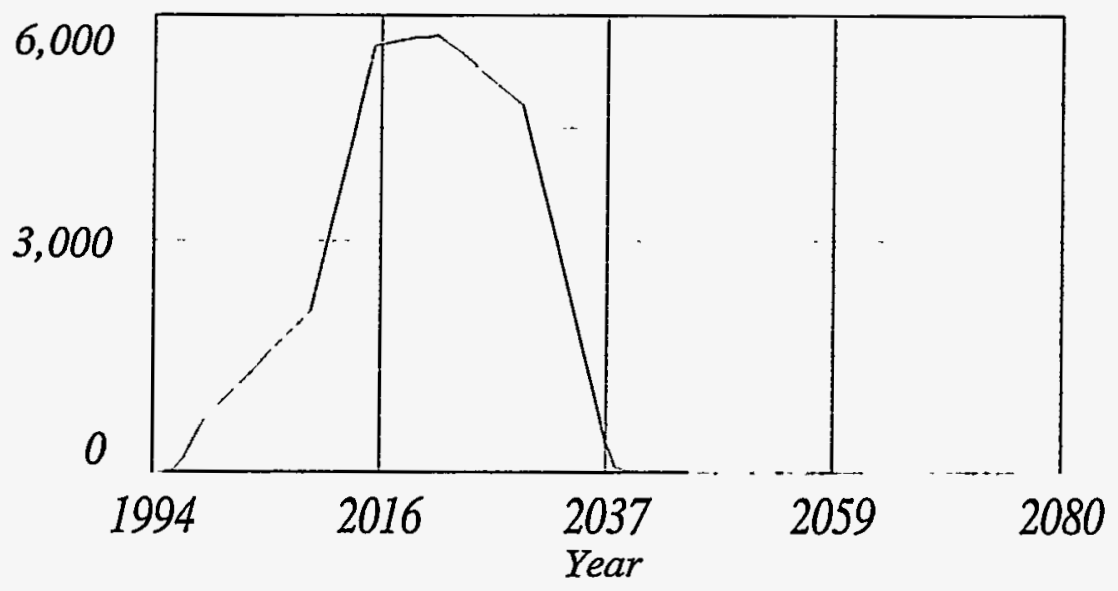

System Interim Storage

Cubic Meters

Figure 3. System Interim Storage Requirements as a function of time (year). The initial slope is attributable to production at SRS, with a brief contribution from WVDP in 1997 and 1998. The steep increase in slope is a result of the start of production at Hanford in 2009. Shipments to the repository begin in 2014. Production at SRS is complete in 2020, and at Hanford in 2028. These events are all marked by decreases in slope. 

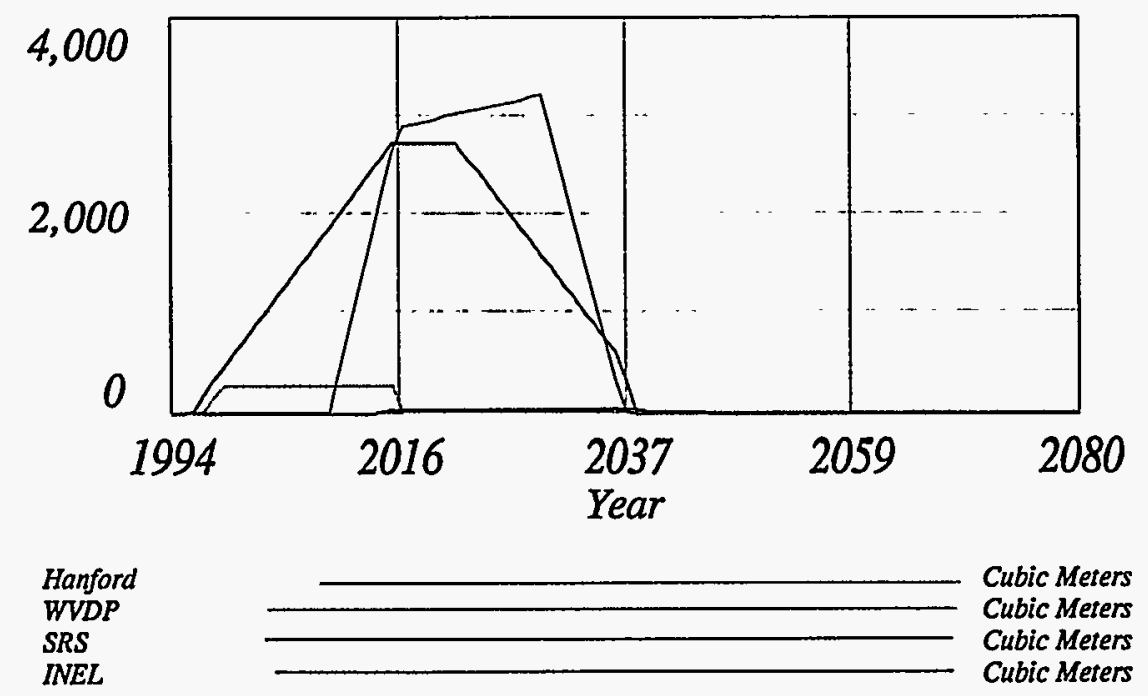

Figure 4. The amount of glass in interim storage at each site as a function of time. Shipments to the repository start in 2015. Interim storage at West Valley is emptied in the first year of repository operation.

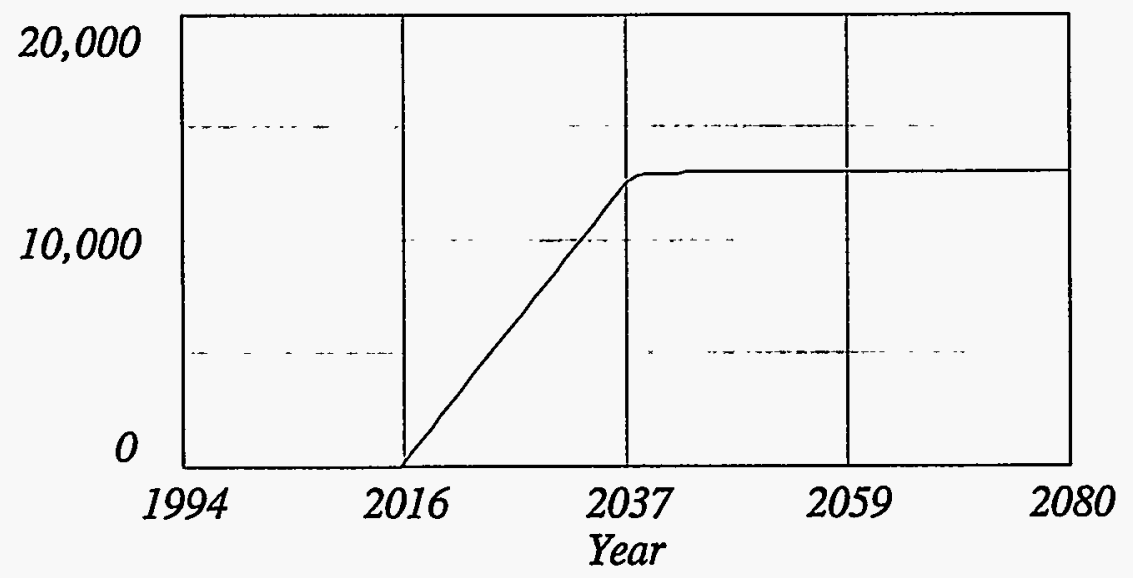

Figure 5. The volume of HLW glass in the repository as a function of time (year). The slope between 2039 and 2044 is slightly positive because the INEL is still shipping glass at the rate of $16 \mathrm{~m}^{3}$ per year. 
In this scenario, interim storage capacity at the INEL reaches a maximum of $41 \mathrm{~m}^{3}$ the year the repository starts receiving $\mathrm{HLW}$, and remains at $41 \mathrm{~m}^{3}$ until interim storage at Hanford is emptied. The INEL ships glass at its production rate of $16 \mathrm{~m}^{3}$ per year until additional transportation/receipt resources become available when Hanford stops shipping. The need for interim storage at the INEL could be eliminated by delaying startup of the vitrification facility from the currently planned 2013 date to 2015 when the repository starts receiving HLW. Alternatively, interim storage could be shut down in 2015 by allocating enough transportation/receipt throughput (reassigning from other sites) to deplete the inventory in one year.

It should be noted that the model indicates that single shell tanks (SSTs) at Hanford will not be emptied until 2022. This date misses the 2018 deadline in the Tri-Party Agreement by four years and probably jeopardizes the 2024 deadline for closure of all SST farms.

The model also calculates the amount of low-level waste generated as a side stream from processing HLW. The low-level waste stream is a result of separations or other processes designed to concentrate the high-activity portion of the waste. This low-level waste stream does not represent all low-level waste generated by the site, nor does it include contaminated "hotel" waste (gloves, booties, wipes, etc.) that may be generated in connection with HLW immobilization. The amount of low-level waste generated by the process is directly related to the amount of HLW processed. Since the amount of HLW processed was not changed in any of the scenarios, the total amount of low-level waste generated does not change. The amount of low-level waste generated in connection with HLW immobilization at each site is shown in Table 1. For this scenario, the low-level waste stream from HLW treatment stops in 1995 for West Valley, in 2004 for Savannah River, in 2038 for Hanford, and in 2043 for the INEL.

Table 1. Low-level waste streams generated by HLW processing at each site.

\begin{tabular}{lc}
\multicolumn{1}{c}{ Site } & $\begin{array}{c}\text { Low-level waste volume } \\
\left(\mathrm{m}^{3}\right)\end{array}$ \\
\hline West Valley & 4,837 \\
Savannah River & 473,184 \\
Hanford & 210,450 \\
INEL & 21,035 \\
\hline
\end{tabular}

\subsection{Scenario 2: No Repository}

Maximum interim storage capacities for each site are shown in Table 2. The rates at which glass will be emplaced in interim storage at the four sites are illustrated in Figure 6.

As can be seen from Figure 6, the largest volumes of glass will be held in interim storage at Hanford and SRS $\left(8783 \mathrm{~m}^{3}\right.$ and $3550 \mathrm{~m}^{3}$, respectively). In contrast, interim storage inventories at West Valley and the INEL will be quite small. At the INEL, the small volume of HLW glass is a result of the high decontamination factors anticipated for the separations processes that are part of the proposed "full-treatment option" that was developed by the INEL to integrate waste treatment and reduce cost. The full-treatment option minimizes the volume of $\mathrm{HLW}$ requiring disposal in a deep geologic 
Table 2. Maximum interim storage capacity of HLW by site, assuming repository opening is delayed indefinitely, scenario 2.

\begin{tabular}{|c|c|c|}
\hline Site & $\begin{array}{l}\text { Maximum interim storage } \\
\text { capacity } \\
\left(\mathrm{m}^{3}\right)\end{array}$ & $\begin{array}{l}\text { End of waste form } \\
\text { production } \\
\text { (year) }\end{array}$ \\
\hline Savannah River & 3550 & 2020 \\
\hline West Valley & 227 & 1998 \\
\hline Hanford & 8783 & 2028 \\
\hline Idaho National Engineering Laboratory & 496 & 2043 \\
\hline
\end{tabular}

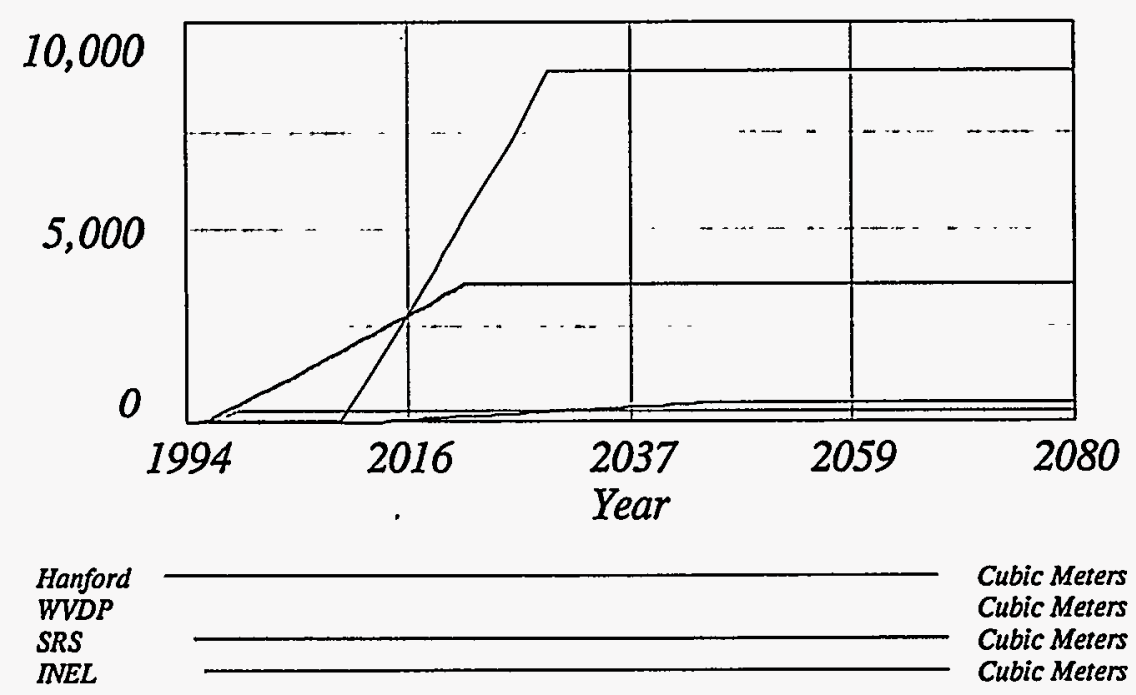

Figure 6. Waste glass emplaced in interim storage at each site as a function of time, assuming repository opening is delayed indefinitely. Interim storage construction schedules can be developed using these data.

repository at the expense of an increase in the volume of low-level waste destined for onsite disposal. For this scenario, the low-level waste streams from HLW treatment are the same as in the base case scenario (Scenario 1).

\subsection{Scenario 3: Reduced Throughput}

The implications for interim storage at each of the four sites are illustrated in Figure 7.

Reduction of the glass production rate (throughput) at Hanford by $30 \%$ dominates this scenario. The total system production rate is thereby sufficiently reduced that Hanford and the INEL can ship glass at the rate of production, thus eliminating the need for interim storage at those sites. At the same time, SRS reduces the glass inventory in interim storage by shipping at a rate higher than the Defense Waste Production Facility's production rate. However, because of the reduced throughput, Hanford will not be able to meet several milestones that are currently in the Tri-Party Agreement. The SSTs 

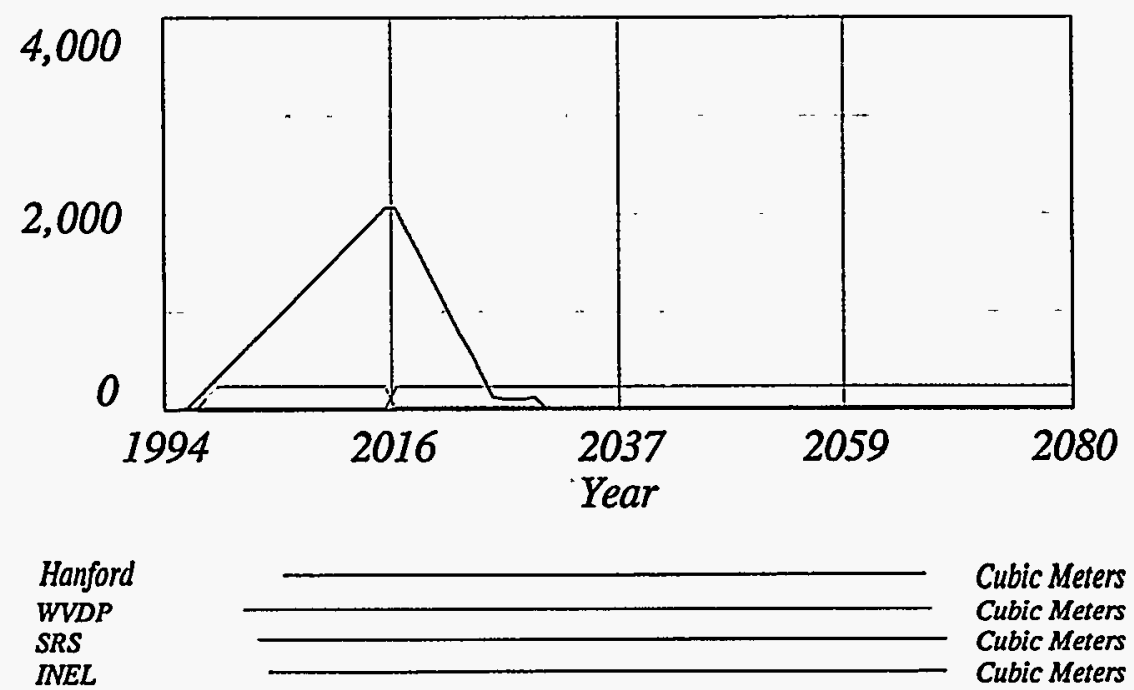

Figure 7. Glass in interim storage at each site as a function of time. The need for interim storage at Hanford and the INEL is essentially eliminated by delaying production at those sites until the repository opens.

will not be emptied until 2034 instead of by the 2018 deadline, which means that closure of all SST farms cannot be completed by the 2024 deadline. Also, waste pretreatment processing and vitrification will not be completed by the 2028 deadline. The INEL's Notice of Noncompliance (NON) Consent Order contains deadlines to cease use of the HLW tanks in pillar and panel vaults by 2009 and all other tank farm tanks by 2015 . While the model does not track tanks in the pillar and panel vaults separately results indicate that the tank farm inventory at the Idaho Chemical Processing Plant (ICPP) is depleted rapidly enough to meet these milestones.

The low-level waste streams from HLW treatment generate the same total amounts of low-level waste as indicated in Table 1. The schedules for the low-level waste streams at West Valley and Savannah River are the same as in the base case scenario (Scenario 1), but Hanford's stream does not stop until 2051, and the INEL's stream does not stop until 2056.

\subsection{Scenario 4: Delay Repository Opening 30 Years}

Under this scenario, shipments to the repository do not begin until 2045. Savannah River, West Valley, Hanford, and the INEL all complete waste form production before that date (in 2020, 1998,2028 , and 2043, respectively), so interim storage capacity must be provided for all waste glass produced $\left(3550 \mathrm{~m}^{3}, 227 \mathrm{~m}^{3}, 8783 \mathrm{~m}^{3}\right.$, and $496 \mathrm{~m}^{3}$, respectively). Interim storage at the INEL remains full for only about one year, because end of production nearly coincides with the beginning of waste shipments. Interim storage at the West Valley site is emptied in 2045 (by definition), but the other sites must remain open until 2065-2066. The waste glass inventory in interim storage at each site as a function of time is shown in Figure 8.

From Figure 8 it can be seen that delaying repository opening by only five years will require maximum interim storage at SRS, and a delay of 13 years will require maximum interim storage at Hanford. These two sites will produce the majority of the system's waste glass, and will, therefore, 

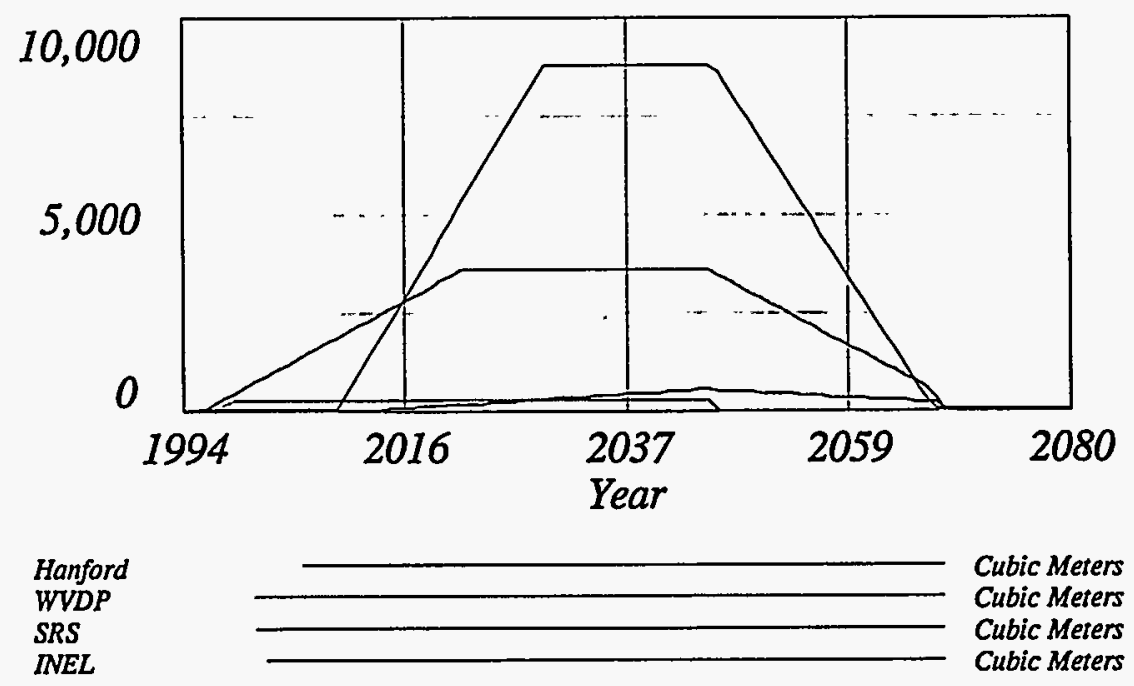

Figure 8. Waste glass inventory at each site as a function of time. In this scenario, each site must provide interim storage capacity for the total amount of waste glass produced. The end of production for a given site is indicated by the point where the interim storage vs. time curve changes from positive to zero.

dominate the system's interim storage capacity. For this scenario, the low-level waste streams from HLW treatment are the same as in the base case scenario (Scenario 1).

\subsection{Scenario 5: Delay Repository Opening 30 Years and Renegotiate Milestones}

Under this scenario, shipments to the repository do not begin until 2045. Since SRS and West Valley already have, or are constructing, facilities, milestones (i.e., schedules) for those sites are not renegotiated. Savannah River and West Valley complete waste form production before the repository opening date (in 2020 and 1998, respectively), so interim storage capacity must be provided for all waste glass produced ( $3550 \mathrm{~m}^{3}$ and $227 \mathrm{~m}^{3}$, respectively). Milestones for Hanford and the INEL are assumed renegotiated to delay construction and allow the beginning of waste form production to coincide with the start of waste shipments to the repository. All waste treatment at Hanford and the INEL, including calcination at the INEL, is delayed 30 years. Milestones from the Hanford Tri-Party Agreement and the INEL's NON Consent Order that would be renegotiated are shown in Tables 3 and 4 respectively, along with the original dates and the renegotiated dates.

Table 3. Top-level milestones from Hanford's Tri-Party Agreement that would be renegotiated under this scenario. Sub-tier milestones would also be renegotiated.

\begin{tabular}{lcc}
\hline \multicolumn{1}{c}{ Top-level milestone-Hanford } & Original date & New date \\
\hline Complete closure of all SST farms & 2024 & 2052 \\
Complete pretreatment processing of Hanford waste & 2028 & 2058 \\
Complete vitrification of Hanford HLW & 2028 & 2058 \\
Complete vitrification of Hanford LLW & 2028 & 2058 \\
\hline
\end{tabular}


Table 4. Top-level milestones from the INEL's NON Consent Order that would be renegotiated under this scenario. Sub-tier milestones would also be renegotiated.

\begin{tabular}{lll}
\hline \multicolumn{1}{c}{ Top-level milestone-INEL } & \multicolumn{1}{c}{ Original date } & \multicolumn{1}{c}{ New date } \\
\hline $\begin{array}{l}\text { Operate New Waste Calcining Facility every } \\
\text { three years }\end{array}$ & Last operated 1993 & Next operation 2026 \\
Cease use of tanks in pillar and panel vaults & 2009 & 2039 \\
Cease use of remaining tank farm tanks & 2015 & 2045 \\
\hline
\end{tabular}

Under this scenario, it may also be necessary to build additional tanks at the INEL. If so, the NON Consent Order requires that preparatory work be completed by the fall of 1996, and construction begin by October 1998 if required by the INEL SNF and ER\&WM EIS ROD. Shipment rates for all sites are assigned as described previously (see Section 3.1). Figure 9 illustrates the impact of this scenario on site interim storage requirements as a function of time.

Interim storage capacity must be provided for all waste glass produced at SRS and West Valley. The amount of glass in storage at Hanford and the INEL reaches maximum $\left(610 \mathrm{~m}^{3}\right.$ and $35 \mathrm{~m}^{3}$, respectively) in 2065, but drop to zero in 2066 . The sudden emptying of interim storage at both sites is a result of the end of waste form production at Hanford. Shipments from the INEL continue at the production rate until 2075 when production ceases.

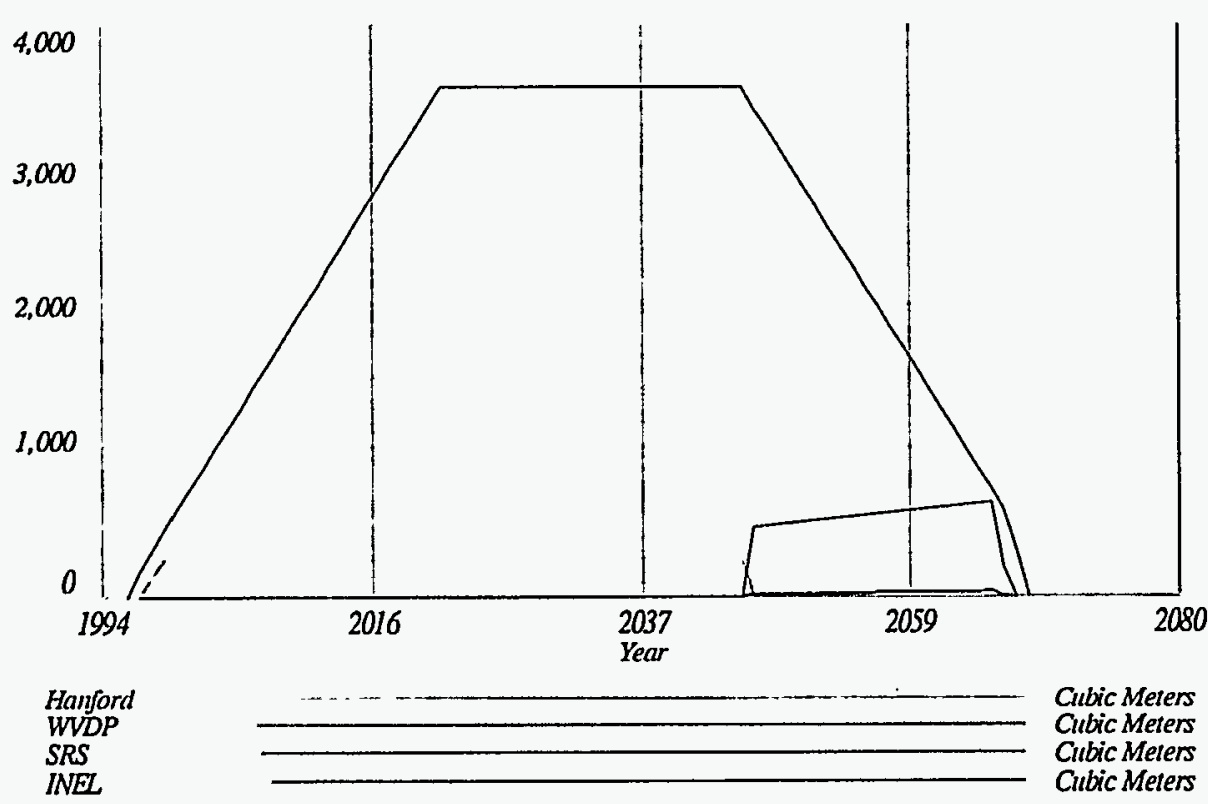

Figure 9. Site interim storage inventories as a function of time. The ends of production for SRS and West Valley are indicated by the points where the interim storage vs. time curve changes from positive to zero. Interim storage must be provided for all waste glass produced at the SRS and West Valley, but concurrent production and shipping schedules minimize interim storage capacities at Hanford and the INEL. 
As can be seen from Figure 9, total system interim storage capacity is dominated by SRS in this scenario. This is a direct result of delaying production at Hanford and the INEL to coincide with repository opening to minimize interim storage needs at those sites. The amount of waste glass in interim storage at those sites increases at all times during Hanford's production campaign because, even after SRS stops shipping, combined production rates at Hanford and the INEL exceed the shipping/receipt rate. From this, it appears that the need for interim storage at Hanford and the INEL could be eliminated from this scenario by slightly reducing Hanford's production rate, or by slightly increasing the transportation/receipt rate.

The low-level waste streams from HLW treatment generate the same total amounts of low-level waste as indicated in Table 1 . The schedules for the low-level waste streams at West Valley and Savannah River are the same as in the base case scenario (Scenario 1), but Hanford's stream does not stop until 2058, and the INEL's stream does not stop until 2073.

\subsection{Scenario 6: Delay Vitrification at INEL to Optimize Hanford Funding}

The requirements for interim storage in this scenario are virtually identical to the base case, except that no interim storage is needed at the INEL. Recall that, even in the base case, very little interim storage is needed for the INEL because the repository started accepting waste shortly after vitrification started. In this scenario, the repository has been operating for 14 years before vitrification begins at the INEL, so glass is shipped to the repository at the production rate. Interim storage requirements by site as a function of time are shown in Figure 10.

From an operational standpoint, the major difference between this scenario and the base case scenario is that the repository must remain open until 2067 to receive production output from the INEL, compared to the 2043 closing date in Scenario 1. After 2037, however, the shipment/receipt

throughput will be significantly reduced because the system will need to handle only the $16 \mathrm{~m}^{3}$ per year production capacity of the INEL.

The low-level waste streams from HLW treatment generate the same total amounts of low-level waste as indicated in Table 1. The schedules for the low-level waste streams at West Valley, Savannah River, and Hanford are the same as in the base case scenario (Scenario 1), but the INEL's stream does not stop until 2067. 

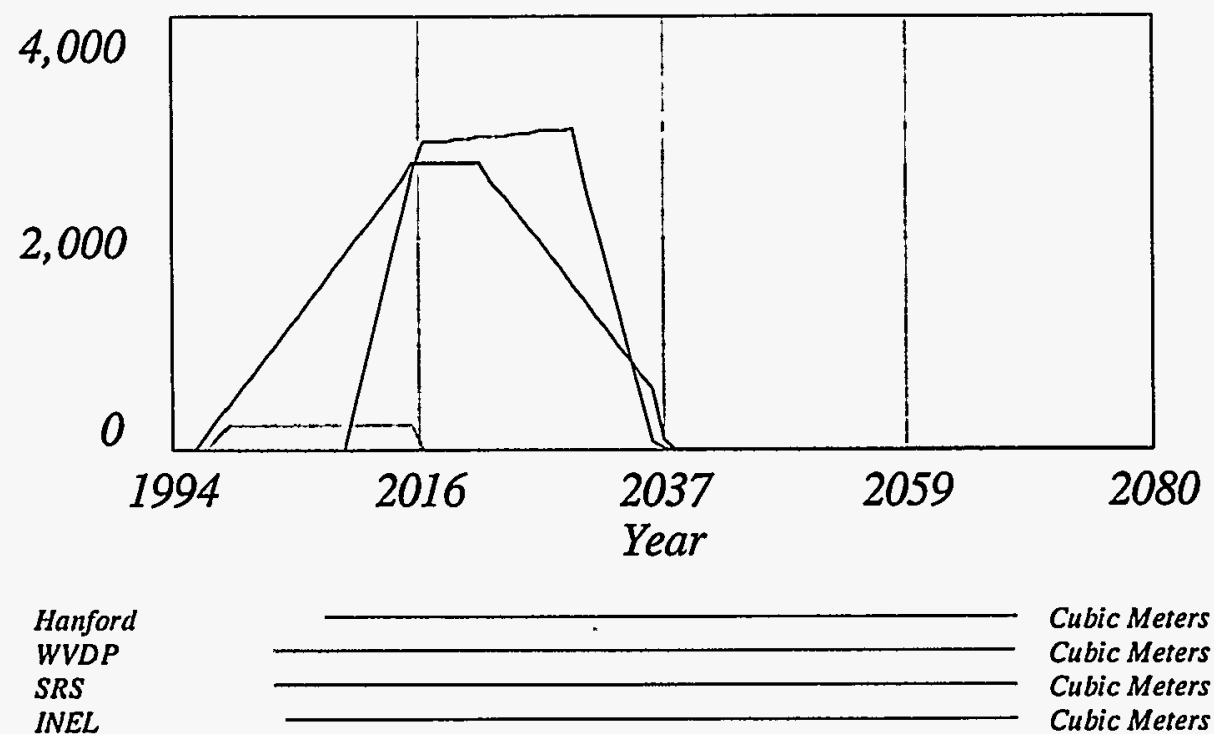

Figure 10. Glass in interim storage at each site as a function of time. System interim storage inventory goes to zero in 2037, but production at (and shipment from) the INEL extends to 2067. 


\section{RECOMMENDATIONS}

\subsection{System Recommendations}

The scenarios used for initial model development suggested several strategies that could reduce technical risk and/or overall system costs. Since the model does not currently evaluate costs, a cost/benefit analysis should be performed on those recommendations that involve significant re-direction of capital funds.

It has been suggested that WVDP glass might be sent to interim storage at SRS to expedite closure of the WVDP site. However, it does not appear that enough excess capacity will be available at SRS for WVDP glass. If SRS builds three interim storage facilities with a nominal capacity of $1200 \mathrm{~m}^{3}$, the resulting storage capacity will be $3600 \mathrm{~m}^{3}$. If SRS produces $3550 \mathrm{~m}^{3}$ of HLW glass, there will not be enough spare capacity for WVDP's $227 \mathrm{~m}^{3}$ of glass. It would seem desirable from a cost savings standpoint to use SRS's modular interim storage design for the interim storage facilities at Hanford. If so, Hanford would require eight of the nominal $1200 \mathrm{~m}^{3}$ facilities, for a total storage capacity of 9600 $\mathrm{m}^{3}$. Since Hanford will produce $8783 \mathrm{~m}^{3}$ of glass, that would leave enough excess capacity not only for WVDP's glass, but for the INEL's glass as well. For scenarios resulting in maximum interim storage requirements, it seems desirable to store INEL and WVDP glass at Hanford, thereby expediting closure of the WVDP site and eliminating the need for interim storage facilities at the INEL.

If the repository opens on schedule (accepting HLW by 2015) and the INEL starts vitrification on schedule (2013), interim storage capacity will be required at the INEL. However, the need for interim storage at the INEL could be eliminated by either delaying vitrification two years and shipping glass directly to the repository at the production rate, or shipping glass to Hanford for interim storage as discussed above.

If interim storage facilities near design life because of a long delay in repository opening, consider replacing site interim storage facilities with a single centralized new facility, preferably located on or near the site of the future repository. This approach would facilitate site closures, and possibly allow downsizing or elimination of transportation resources. A cost/benefit analysis should be performed to evaluate this option.

The most obvious strategy for minimizing facility cost is to minimize or eliminate the need for interim storage facilities. Interim storage is most readily minimized if vitrification can be delayed until the repository is ready to accept HLW. Since SRS and WVDP are nearly ready to start vitrification, it may be neither practical nor desirable to delay those sites. However, it may be possible to reduce costs at Hanford and the INEL by tying vitrification to the repository schedule. Assuming that transportation capacity is available, direct shipment to the repository at the sites' production rates would eliminate interim storage except for some small surge capacity. However, delaying HLLW treatment at Hanford is probably unacceptable because of the deteriorating condition of the SSTs. Calcination is used at the INEL to convert HLLW into a safer, solid form for interim storage. A technical and cost/benefit analysis should be performed to evaluate the possibility of using INEL's calcining technology on Hanford's HLLW to reduce the risk of interim storage, and allow vitrification to be delayed until a repository is ready.

\subsection{Recommendations for Future Work}

The current model focuses on HLW issues in terms of how they affect the schedules for waste immobilization and the flow of waste through the system. Cost is another important factor for the HLW 


\section{REFERENCES}

Idaho Department of Health and Welfare, 1994, Consent Order for the United States Department of Energy, Idaho National Engineering Laboratory, April 3, 1992, as amended March.

Murphy, J. A., et al., 1995, ICPP Radioactive and Calcine Waste Technologies Evaluation and Final Report Recommendation, INEL-94/0119, Lockheed Idaho Technologies Company, April.

RW (Office of Civilian Radioactive Waste Management), 1993, Waste Acceptance System Requirements Document (WASRD), RW-0351P, Revision 0, January.

Westinghouse Hanford Company, 1994, Hanford Site Tank Waste Remediation System Technical Strategy, Revision 0, March 18.

Westinghouse Savannah River Company, 1994, High-Level Waste System Plan, Revision 4 (U), HLW-OVP-94-0145, November 30.

Lockheed Idaho Technologies Co., 1995, Integration of EM Activities at the INEL, March 31. 